\title{
Analysis of Trends of the Sustainable Development Strategy of Coal Industry in Kuzbass
}

\author{
Irina Dymova ${ }^{1}$, Yanina Formulevich ${ }^{2}$, Olga Karpova, ${ }^{2,}$, and Igor Lyamkin ${ }^{2}$ \\ ${ }^{1}$ T.F. Gorbachev Kuzbass State Technical University, 650000, 28 Vesennyaya St., Kemerovo, Russia \\ ${ }^{2}$ Kemerovo state university, 650000, 6 Krasnaya st., Kemerovo, Russia
}

\begin{abstract}
The article analyzes the trends of the strategy of sustainable development of coal industry in Kuzbass and the prospects for its development. The main problems connected with the coal enterprises operations are identified, possible ways of their solutions are presented within the framework of the adopted "Strategy for social-and-economic development of the region for the period up to 2035". Having analyzed the program under study, the proposals for its correction or addition in terms of improving the ecology of the region, social-and-economic development, preserving the natural landscape and biogeocenosis were made. The options for transporting coal and increasing the level of coal production technologies in underground mining were proposed. The article provides statistical data on coal mining for the period 2009-2020, and international experience of coal-mining countries. The authors consider the problems of export and transportation of coal, the impact of world prices on coal production. In addition, the authors of the article focus on the legal and legislative consolidation of the main conditions for control and regulation of the subsoil use in Kuzbass, make proposals for its effectiveness, in order to reduce social tension, environmental pollution, reduce the risk of earthquakes, and preserve coal resources for future generations.
\end{abstract}

\section{Introduction}

In the economy of Kuzbass and Russia as a whole, the coal industry occupies an important position. The development of this industry depends on intensive mining, production volumes, the development of new geotechnologies and innovations in the industry. In addition, the export potential of Kuzbass is directly related to the development of the coal industry. The belief in the development of the coal industry is due to its high resource potential. The reserves of brown coal in Russia account for $60 \%$ of all coal rocks, coal accounts for $45 \%$, the rest is occupied by anthracite. According to these indicators, Russia occupies the second place in the world after the United States. The subsoil fund of Russia contains 40.1 billion tons of coal, of which 9.5 billion tons is brown coal [1].

Kuznetsk Basin is geographically located in the Kemerovo region and belongs to one of

\footnotetext{
* Corresponding author: oskarp@yandex.ru
} 
the largest coal mining regions in the world. Despite the crisis in the coal industry over the past 5 years and the decline in the level of world prices, the demand for coal is not falling. Kuzbass in these conditions is the leading coal mining region of Russia. According to many scientists, Kuznetsk Basin retains an advantage in terms of the industry infrastructure and the mining technical conditions of its production. The growth in the dynamics of coal production in Kuzbass has been observed since 2009. Until 2014, the increase in coal production was about 5.5 million tons per year. In the period from 2015 to 2020 inclusive, the increase was more than doubled. According to geologists, the explored coal reserves in the Kemerovo region will last for 250 years [2]. According to the Department of Coal Industry of the Administration of the Kemerovo region, 267.3 million tons of coal were mined in 2019. This was more by 14 million tons than in 2018 and $60 \%$ of them were mined by open pit mining [3]. The development of the coal industry at such a pace is a positive factor for the Kuzbass economy, but there is a downside to this development. Open pit mining destroys agricultural and natural lands, the ecological situation is deteriorating, the number of oncological and other types of diseases is growing, as well as social tension in the region. In turn, the emergence of new areas of coal mining creates a threat to the destruction of the natural landscape and settlements. Open pit coal mining moves to the territory where there are relict linden forests, the channels of the large rivers of the Kuznetsk Alatau, Gornaya Shoria, Salair ridge. The steppe, wetland and sodic soils of Kuznetsk Basin fell into this ecological territory [4].

The lack of export opportunities is another problem of increasing coal production. This caused a decrease in the loading volumes of Kuzbass coal and failure to fulfill the obligations of Russian Railways. Insufficient throughput of the Eastern landfill led to the downtime of loaded trains. The consequence of this situation was a decrease in production volumes, a reduction in the working hours of coal enterprises, massive layoffs of their employees, and an increase in unemployment [5].

\section{Materials and Methods}

It's necessary to consider the main document regulating the social-and-economic development of the Kemerovo region - the "Strategy for social-and-economic development of the region for the period up to 2035". This document contains the directions of strategic development of the main industry in Kuzbass, which makes it possible to consolidate the role of the region as a national leader in the segment of coal mining and processing, as well as generating energy from coal [6]. The analysis of directions of the coal industry strategic development consist of the following

1. Ensuring coherent strategies. This clause includes the following areas:

- the development of coal mining and coal processing requires constant coordination of actions, taking into account the interests of Kuzbass inhabitants, appropriate approvals with the authorities of different levels and the interests of private business in this industry;

- creating the association of coal producers in Kuzbass;

- increasing the efficiency of coal power electricity and the environmental friendliness of coal TPPs based on "clean coal" technologies;

- the need for developing transport and trade infrastructure;

- introducing innovative methods and technologies for coal combustion using supercritical steam parameters.

In this context, the direction requires the participation of science, government and business. In the scientific field, it is necessary to develop a complex of innovations in the field of chemistry, energy, and economics. On the part of the state, it is necessary to develop legislative normative documents controlling and regulating the process of coal mining, which 
would contribute to the balance of all systems involved in this process: ecological, economic, social [7].

2. Increasing the financial sustainability of labor productivity in coal industry:

- achieving an optimal level of capital structure and reducing the cost of coal mining. Reducing the cost does not mean reducing the cost of the safety of the production process;

- reducing the costs for the transportation of coal by rail and road.

This direction can be fully realized only in the conditions of coordination of actions for all parties involved in the economic system of coal mining industry. Points in this direction require the solution of problems at the national level. The owners of coal enterprises must review, evaluate and understand the process of making a profit and link it with the safety of the labor process, the search for new export points, compliance with environmental standards, etc.

3. Increasing the efficiency of coal mining companies and the coal industrial complex through the creation of infrastructure and logistics projects. In this direction, it is provided:

- the use of public-private partnerships to stimulate the development of transport and logistics infrastructure;

- the development of new export directions;

- the development of transport system in Kuzbass, coordinated with the development of railway transport and sea trade ports of Russia.

This direction requires radical transformations of Kuzbass transport system and additional investments into the coal industry.

4. Environmental protection in the processes of coal mining and coal processing. In this direction, emphasis should be placed on the inventory of disturbed lands and ecosystems, designation of areas that are no longer intended for mining and their further reclamation. To do this, it is necessary to remove such lands from the balance of mining enterprises. Territories and settlements that have been flooded, have consequences for the environment, change the hydrological regime, and require a special environmental assessment.

5. Improving the environmental friendliness of coal electricity. This direction provides the creation of innovative and energy-efficient facilities operating on coal and products of its processing, the introduction of advanced technologies of "clean coal" in Kuzbass. Such options for the development of this direction will become possible only if the tunneling and mining equipment of the coal industrial complex is fully modernized.

Kuzbass is not only a large coal mining region, but also a major supplier of coking coal, which has a high value on the world market. In the future, it is necessary to intensify this direction of coal industry development. This is impossible without a return to underground mining. Now in Kuzbass there is a period of open-pit mining, which, according to analysts, may last for 20-30 years [8]. During this period, it is necessary to implement the goals and objectives of coal industry development outlined in the strategy, create new technologies for underground mining, new approaches to preserving the environment, subsoil, agricultural land, natural ecosystems. These technologies should provide the improvement of safety for miners and mining workers. However, the strategic development program of the Kuzbass coal industry until 2035 does not provide such aspect of industry development. The problem is caused by the chaotic use of subsoil and inadequate regulation and control by the state.

In this regard, it is advisable to propose new mechanisms for regulating and controlling this situation. A competitive procedure for granting the right to use subsoil should be added to innovative behavior. One of the competition terms should be the submission of proposals for the development and implementation of new mining technologies focused on the extraction of low-tech coal reserves. For this, at the stage of the competition, there is a need for scientific and analytical assessment of the state of the mineral resource base, an assessment of the state balance of coal reserves, and consolidation of the scientific concept of "high-tech reserves" at the legislative level. 
Open pit mining in the region causes constant social tension among the population. It is caused by the great concentration of the existing and under construction open-pit mines around the settlements. This is due to the lack of a general scheme for the development of deposits by private owners of coal companies. As a result of such actions there is irrational placement and a high level of land acquisition for open-pit mines and dumps. Inconsistency between the business structure and the state requires attention of the "Strategy for social-andeconomic development of the region for the period up to 2035". The dynamics of land disturbance is $12 \mathrm{sq}$. km. per year, which is 1200 hectares of land [9].

Open pit coal mining is one of the reasons for seismic activity in the Kemerovo region. For example, in 2013, one of the strongest industrial earthquakes occurred at the epicenter of 7 on the MSK-84 scale on the territory of a large coal mine "Bachatskiy". The cities of Belovo, Polysaevo, Leninsky-Kuznetsky, Guryevsk were included in the five-six point zone. The earthquake waves were felt in the Novosibirsk region, in the Altai Territory with a magnitude of 3-4 points [10].

Until now, Kuzbass has not taken into account the existence of such a concept as an environmental restriction on coal mining. This concept should be scientifically substantiated and have a quantitative expression. The strategic program for the industry development does not consider this issue.

\section{Results and Discussion}

There are no alternative options for the Kemerovo region development, except as a raw material region, primarily coal. The main problem is not that we have to refuse from the coal industry development, but it is necessary to change the approach to its development and give it a new quality. The basis should not be the "monetization" of all ongoing processes, but their "socialization". Applied innovations, scientific approaches should not only enrich investors and owners of coal enterprises, but also improve the quality of life of the population, work for the preservation of environmental safety, the preservation of nature and bio systems.

Let us give an example of international experience in the harmonization of raw material territories. This experience is practiced by many countries: Canada, Norway, Australia, etc. The basis of economic development is the extraction of resources as a tool or mechanism for the development of territories. Currently, such harmonization has not yet been achieved in Kuzbass, and coal mining is a tool for maximizing income from resource extraction.

Within the framework of the program for the coal industry strategic development, the emphasis is on the fact that the image of the region is based on harmony with coal. It is more correct to perceive Kuzbass not as an endless source of coal deposits and reserves, but as a source of growth in the welfare of the population living on its territory.

Most experts in the field of economics and politics are of the opinion that the coal industry a priori cannot be considered as a source of Kuzbass development. The emphasis in this opinion is on the fact that raw materials are running out, the uncontrolled opening of openpit mines and the use of coal subsoil is depleting coal reserves, and transformation and development strategy are useless. The value chains created in the region are formed on the basis of coal mining and processing. The export-oriented development model has led to the fact that the region is mainly focused on the first production stages with a minimum number of production nodes (centers), which are characterized by such features as capital intensity, low demand for a highly productive labor force, research and development, lack of interest in development related and supporting industries. This explains the region's insensitivity to innovations, the stability of its single-industry structure, and the complexity of economic diversification. [11] From our point of view, this position is erroneous for the following reasons. First, although historically value chains in the region were built on the basis of coal 
(coal - coke - coke oven gas, phenol, benzene, paraffin - ammonia, ethylene, propylene ammonium nitrate, organic matter - explosives, plastics, dyes, pharmaceuticals), coal as a feedstock does not affect chain building in other industries that are based on natural gas and oil. Secondly, the "export-oriented model" is not a goal, but the result of optimizing coal business models. Thirdly, if we are talking about the type of economic activity "extraction of fuel and energy minerals" (for Kuzbass, in fact, a synonym for "coal industry"), it is appropriate to recall the fundamental difference in the social essence of regions and firms.

To harmonize all areas of coal industry development, it is necessary to consider attracting highly qualified labor force for the development and use of science-intensive technologies. At present, there are 54 processing plants in the region. The enrichment technologies used on them have no analogues in the world. Half of them has been created during the last 15 years.

Features of coal production provide the liquidation of the coal enterprise. The liquidation of such enterprises should take place taking into account the preservation of the ecology of the territory. Since after the closure of the mines it is impractical to use the source of their financing, there is no "dry" method of liquidation. In the strategic development program, it was possible to propose the creation of funds that concentrate the enterprises' finance in the constituent entities of the Federation. The finance of such funds should be used to provide the financing of permanent measures for pumping water, eliminating the consequences of collapse, etc. The presence of a regional liquidation fund in Kuzbass will ensure that reclamation of previously disturbed territories is ahead of mining operations.

Maintaining an ecological balance in coal industry can be achieved in the following ways: 1. Taking into account the time limits of the impact of existing coal mining enterprises on the environment. This is reflected in the pollution of water and air basins, soil, a decrease in the catchment area, destruction of agricultural land, degradation of the biogeocenosis of the territory.

2. Assessment of changes in the environment and ecological situation after the completion of the coal enterprise work. This method is complicated by the fact that the climate of the region is of a sharply continental nature and there is no technology for its accurate forecasting yet. In addition, after a quarry or open pit is poured, a manmade lake appears. Here there is a lack of assessment of the rock mass deformation and its further behavior. Today, the volume of underground space destroyed in Kuzbass exceeds 150 billion cubic meters.

In this case, a year before the liquidation of the coal enterprise, a project for the completion of the development of a subsoil plot should be developed. This is the only way to avoid the consequences of the coal enterprise liquidation on the territory environment. In addition, this project should contain ways to restore the biogeocenosis of the natural zone, land reclamation, and so on. These studies have shown the need for regulatory changes in the assessment of "ecological coal mining capacity".

It is advisable to pay attention to the perception of coal as a raw material. For the development of the economic component, strengthening the sustainability of the coal industry development, it is necessary to transform the coal cycle of production and processes around coal. Of the various possible directions for using coal at a sufficiently high level, only metallurgical is developed, energy is hypertrophied, and promising chemical is very weak. As a consequence of this very structure of the coal production cycle in Kuzbass, a one-sided export orientation was formed and, as a result, we observe the vulnerability of the coal industry to world prices and demand for coal. Of the primary coal processing, production facilities for its enrichment correspond to international standards.

The coal production cycle that has been developed in Kuzbass has all the necessary conditions for increasing methane extraction, developing semi-coking, generator, and, under certain conditions, underground gasification, as well as for the production of ultrapure coal, motor fuels and more than a hundred types of other products. Researches in this direction are fragmentary. They do not have the necessary financial support and are mainly focused on 
small-scale production.

\section{Conclusion}

Analysis of the trends of the sustainable development strategy of the coal industry in Kuzbass showed the need for a comprehensive study of this process. The main goal of such a deep study of the issue is the lack of consideration of all aspects of the strategic development of coal industry.

The Kuznetsk coal competitiveness is undermined by a high transport component, the growth of which is outstripping the rise in prices for transported products. This is due to the geographic location of Kuzbass, whose territory is far from the main consumers, cargo ports for transshipment of coal, and the insufficient capacity of railways for the increasing volume of coal production.

Earlier in the USSR, a project for the Kuzbass-Ural coal pipeline with a length of 2,400 $\mathrm{km}$ was developed (it was about the transport of ordinary pulp, and not about the transport of a specially prepared type of fuel - coal-water, to which the infamous Belovo-Novosibirsk pipeline was oriented). For many years, a coal pipeline from the Yubileinaya hydraulic mine to the West Siberian Metallurgical Plant (a little more than $20 \mathrm{~km}$ ) operated in Kuzbass, which ceased to exist only in connection with the mine liquidation. The experience of using pipeline transport is also available in a number of other countries, primarily in the United States. For example, in 1970 the Black Mesa coal pipeline was built there with a length of $440 \mathrm{~km}$ and a cargo flow of 4.8 million tons of coal per year, which was served by about 50 people. There are known coal pipelines projects with a length of several thousand kilometers with a capacity of more than 30 million tons of coal per year. Coal pipelines, in comparison with railway transport, have a number of advantages:

- continuity and uniformity of freight traffic;

- constancy (averaging) of the quality of the delivered product;

- independence of work from weather conditions and the absence of negative impact;

- high potential for the automation of transport and loading and unloading operations;

- the possibility of the associated production of rare and valuable elements in the process of waste water treatment;

- decreasing unit cost with increasing the distance of transportation.

In this regard, we can propose to consider the option of transportation by coal pipeline.

The system of organizing coal production is very sensitive to changes in world prices. In this case, it is advisable to propose the introduction of group licensing of subsoil. Then it can be expected that the impact of changes in world prices may decrease.

Analysis of the state of Kuzbass mineral resource base shows that the share growth of open-pit coal mining, primarily coking coal, observed in the region is a temporary phenomenon. To preserve the resource significance of the basin, it is necessary to provide in its development program the implementation of activities on the development of new technologies for underground coal mining, focused on the exploration of reserves, which are considered low-tech now. At the same time, it is appropriate to take into account the ecological component and the level of social-and-economic development. Thus, we can conclude that the trends of the sustainable development strategy of the coal industry in Kuzbass requires additions and their legislative consolidation at the state level. 


\section{References}

1. Kemerovo Region Administration. The official website. URL: https://ako.ru/.

2. Rosstat, Coal mining dynamics in Russia. URL: http://www.gks.ru

3. R. Kotov, The Impact of Kuzbass Industrial Enterprises on Environmental Safety (NRES, Barnaul, 2020)

4. O. Karpova, I. Pevneva, I. Dymova, T. Kostina, S. Li, E3S Web Conf. 21, 04023 (2017)

5. N.K. Sedykh, I.N. Tchaikovskaya, Economics and Innovation Management, 1, 74-83 (2021) DOI: 10.26730/2587-5574-2021-1-74-83

6. O.E. Kalenov, S.N. Kukushkin, Economics and Innovation Management, 3, 88-96 (2020) DOI: 10.26730/2587-5574-2020-3-88-96

7. A.N. Tokarev, Economics and Innovation Management, 1, 25-35 (2018) DOI: 10.26730/2587-5574-2018-1-25-35

8. S. Zhironkin, A. Selyukov, M. Gasanov, Energies, 13(13), 3305 (2020)

9. T.V. Kiseleva, V.G. Mikhailov, Ya.S. Mikhailova, Economics and Innovation Management, 1, 63-73 (2021) DOI: 10.26730/2587-5574-2021-1-63-73

10. M. Cehlár, J. Janočko, Z. Šimková, T. Pavlik, E3S Web Conf. 15, 01019 (2017)

11. A.N. Tokarev, Economics and Innovation Management, 3, 46-51 (2017) DOI: $10.26730 / 2587-5574-2017-3-46-51$ 